\title{
O gênero de discurso científico e as práticas discursivas sobre animais não humanos
}

\section{Speech genres and discourses practices about non-human}

\author{
animals
}

\author{
Verônica Franciele Seidel ${ }^{1}$ \\ Charlies Uilian de Campos Silva²
}

\begin{abstract}
RESUMO: Entendemos, conforme a perspectiva bakhtiniana, que nenhum fato da natureza tem significado em si mesmo, mas que tal significado surge justamente por meio da língua. Sendo assim, a análise dos fenômenos linguísticos auxilia a compreender os posicionamentos ideológicos que sustentam os discursos e, consequentemente, as práticas humanas. A partir disso, pretendemos entender como os animais não humanos (denominados usualmente de cobaias) e as práticas que os envolvem, com enfoque à experimentação laboratorial, são percebidas e apresentadas pelo gênero de discurso científico, bem como de que forma tal visão auxilia a estruturar as relações que com eles estabelecemos. Para isso, analisamos um artigo científico, utilizando como categorias de análise a noção de gênero do discurso. Percebemos, no discurso analisado, a perspectiva de que o emprego de animais é imprescindível ao progresso da ciência, de modo que toda atividade contrária à realização de tal prática é vista como radical e prejudicial ao desenvolvimento científico.
\end{abstract}

PALAVRAS-CHAVE: Língua. Ideologia. Experimentação científica.

ABSTRACT: We understand, according to the bakhtinian perspective, that no fact of nature has meaning in itself, but the meaning just arises through language. Thus, the analysis of language helps to understand the ideological positions that support the discourses and consequently human practices. From this, we aim to comprehend how non-human animals (usually called guinea pigs) and the practices involving them, focused on laboratory experimentation, are perceived and presented by the scientific discourse genre, as well as how such a vision contributes to structure the relations we establish with them. For this, we analyzed a scientific article, using as category of analysis the notion of speech genres. We realize, in the analyzed text, the perspective

\footnotetext{
${ }^{1}$ Universidade Federal do Rio Grande do Sul - UFRGS. Mestre em Letras pela UFRGS. Contato: veronicaseidel@gmail.com.

2 Universidade Federal do Rio Grande do Sul - UFRGS. Doutorando em Letras pela UFRGS. Contato: uilian.campos@restinga.ifrs.edu.br.
} 
that the use of animals is essential to the progress of science, so that any activity contrary to the performance of this practice is seen as radical and harmful to the scientific development.

KEYWORDS: Language. Ideology. Scientific experimentation.

\section{Introdução}

Nenhum fenômeno da natureza tem significado em si mesmo. É justamente por meio da discursivização que algum significado será atribuído a este ou àquele fato. Podemos dizer, desse modo, com base em Bakhtin (2010), que um discurso é sempre motivado por um reflexo do mundo objetivo, isto é, do mundo dos objetos, na consciência de alguém. Tal reflexo será expresso por esse alguém por meio da língua, de modo que todo discurso sempre será dotado de determinado valor, demonstrando certo posicionamento por parte daquele que o enuncia.

Muito embora as discussões acerca da imparcialidade de alguns discursos tenham avançado consideravelmente nos últimos anos, ainda se confere uma posição de destaque aos discursos científicos, como se estes fossem detentores de uma verdade única e insubstituível. Quando consideramos, de um ponto de vista dialógico da língua, que a verdade, o belo ou o justo não se encontram no objeto em si, mas refletem noções construídas a partir do discurso sobre a realidade material, percebemos que 0 conhecimento científico não é neutro.

No campo das Ciências Biológicas, por exemplo, é perceptível a coexistência de dois discursos que, embora imparciais, demonstram uma tensão de valores, ou seja, são estruturados a partir de eixos valorativos diferentes. Enquanto um deles afirma a igualdade em termos evolutivos das espécies, outro, embora reconheça tal igualdade, sustenta uma posição de supremacia para os seres humanos em detrimento dos demais seres vivos. Supremacia essa que permite desde o uso de animais em experimentos até a sua criação para o consumo alimentar humano. 
Tais discursos refletem e refratam as relações entre os homens, conforme explicita Bakhtin (2010), mas também as relações entre os homens e outros seres vivos, pressupondo um sistema aceito no âmbito da comunidade científica, isto é, tomando determinado paradigma como verdadeiro, que, no caso das Ciências Biológicas, consiste em uma igualdade evolutiva entre as espécies. Essa igualdade se deve ao fato de que o objetivo primevo das espécies é se adaptar ao meio ambiente a fim de se reproduzir e, com isso, passar seus genes às próximas gerações (DARWIN, 2003; DAWKINS, 1979). Desse modo, todas as espécies, embora possam ser mais complexas ou mais derivadas, por terem passado por mais modificações estruturais com o passar do tempo, apresentam o mesmo grau evolutivo, já que todas, de um modo ou de outro, estão adaptadas ao meio em que vivem. Logo, do ponto de vista evolutivo, os seres humanos não seriam superiores ou mais evoluídos que as demais espécies e, consequentemente, não poderiam fazer uso destas conforme ocorre em nossa sociedade, pelo menos não segundo esse pressuposto.

Tendo isso em vista, pretendemos analisar, neste estudo, o modo como o gênero de discurso científico percebe e representa os animais não humanos em seus enunciados sobre a prática da experimentação laboratorial. Para isso, analisamos um artigo científico acerca da experimentação em animais, utilizando como categoria de análise a noção de gênero do discurso, explicitada a seguir.

\section{Gênero de discurso: conceito e implicações ${ }^{3}$}

Para Medviédev (2012, p. 193), em qualquer estudo sobre a língua, dever-se-ia partir justamente do gênero, já que este "é uma forma típica do todo da obra, do todo do enunciado" e que uma "obra só se torna real quando

\footnotetext{
${ }^{3}$ Os conceitos de gênero do discurso aqui apresentados foram formulados pelo Círculo de Bakhtin.
} 
toma a forma de determinado gênero". Além disso, uma vez que o significado construtivo de cada elemento em uma obra só pode ser compreendido em sua relação com o gênero, não é possível atribuir um significado autônomo aos elementos abstratos e isolados da língua.

Já no que se refere à determinação temática dos gêneros, o pensador russo defende que "cada gênero é capaz de dominar somente determinados aspectos da realidade", pois "possui certos princípios de seleção, determinadas formas de visão e de compreensão dessa realidade" (MEDVIÉDEV, 2012, p. 196). O autor afirma no entanto, que a conceituação da unidade temática como algo formado pela combinação dos significados de suas palavras e orações isoladas, como entendem os formalistas, não é válida, já que o tema se forma com a ajuda desses elementos, mas não deriva deles, ou seja, não pode ser reduzido às formas linguísticas (elementos verbais de uma obra).

O tema é constituído, assim, pelo todo do enunciado, "considerado como determinado ato sócio-histórico. Por conseguinte, o tema é inseparável tanto do todo da situação do enunciado quanto dos elementos linguísticos". Isso significa que o tema não pode ser separado das circunstâncias espaciais, temporais e sócio-históricas, do gênero a que pertence. Logo, conforme entende Medviédev, "entre a primeira e a segunda orientação da obra na realidade (orientação imediata a partir de fora e temática a partir de dentro), estabelecese uma ligação e uma interdependência indissolúveis. Uma é determinada pela outra. A dupla orientação acaba por ser única, porém, bilateral" (MEDVIÉDEV, 2012, p. 196-197).

Por essa perspectiva, podemos afirmar que o gênero concilia a unidade temática da obra e seu lugar real na vida. Nas palavras de Medviédev (2012, p. 197), "as formas determinadas da realidade da palavra estão ligadas a certas formas da realidade que a palavra ajuda a compreender. [...] O gênero é a unidade orgânica entre o tema e o que está além dos seus limites". Importa ressaltar, assim, que, 
Se abordarmos o gênero do ponto de vista da sua relação interna e temática com a realidade e sua formação, então, podemos dizer que cada gênero possui seus próprios meios de visão e de compreensão da realidade, que são acessíveis somente a ele. Assim como a arte gráfica é capaz de dominar aspectos da forma espacial que a pintura é incapaz de alcançar e vice-versa, igualmente, nas artes verbais, os gêneros líricos, para dar um exemplo, possuem meios de atribuir forma conceitual à realidade e à vida que são inacessíveis ou menos acessíveis à novela ou ao drama. [...] Cada um dos gêneros efetivamente essenciais é um complexo sistema de meios e métodos de domínio consciente e de acabamento da realidade (MEDVIÉDEV, 2012, p. 198).

Medviédev explicita, então, que, embora a língua exerça papel fundamental na tomada de consciência e de compreensão da realidade, esse processo ocorre por meio das formas do enunciado (unidades reais da comunicação discursiva) e não das formas linguísticas (palavras e frases). Assim, é possível afirmar que "a consciência humana possui uma série de gêneros interiores que servem para ver e compreender a realidade" (MEDVIÉDEV, 2012, p. 198). Isso significa que toda nossa compreensão e orientação em relação à realidade e às nossas ações no mundo acontecem justamente com base em gêneros, os quais nos oferecem uma série de procedimentos para isso, cada um ao seu modo.

Dessa maneira, também nosso modo de representação daquilo que apreendemos acerca do mundo ocorre com base na organização de determinado gênero, fazendo com que um artista e um cientista, por exemplo, entendam alguns aspectos da realidade e não outros e que esses aspectos sejam representados também de forma distinta. Podemos entender, assim, que "o gênero é um conjunto de meios de orientação coletiva na realidade" e que essa orientação "desenvolve-se e origina-se no processo de comunicação socialideológica" (MEDVIÉDEV, 2012, p. 198).

Bakhtin (2010), por sua vez, comenta que, entre o discurso e seu objeto, há um meio formado pelos discursos dos outros sobre esse mesmo objeto ou tema, normalmente difícil de ser penetrado. Assim, seria justamente no processo de interação com esse meio que o discurso poderia individualizar-se e elaborar-se estilisticamente e semanticamente. Isso ocorre porque todo 
discurso encontra seu objeto já avaliado, contestado, desacreditado pelos outros discursos que já falaram sobre ele.

O objeto está amarrado e penetrado por idéias gerais, por pontos de vista, por apreciações de outros e por entonações. Orientado para o seu objeto, o discurso penetra neste meio dialogicamente perturbado e [...] se entrelaça com eles em interações complexas, fundindo-se com uns, isolando-se de outros, cruzando com terceiros; e tudo isso pode [...] influenciar todo o seu estilo (BAKHTIN, 2010, p. 86).

Desse modo, todo enunciado surge em determinado momento social e histórico e interage, obrigatoriamente, com outros discursos tecidos pela consciência ideológica sobre determinado objeto. Esse processo dialógico pode ser representado, conforme entende Bakhtin (2010), por um discurso-raio que tenta alcançar determinado objeto. No momento de seu disparo, inevitavelmente, esse discurso se encontrará com outros dizeres sobre o mesmo objeto, fundindo-se com eles, afastando-se deles, enfim, fazendo brilhar uma série de avaliações até alcançar seu objeto.

Isso significa que nenhum discurso pode escapar dessa interação dialógica com o já dito, pois sempre encontrará, em seu percurso até o objeto, outros discursos com os quais irá estabelecer um embate ideológico constitutivo de si mesmo. Desse modo, podemos afirmar, nas palavras de Bakhtin (2010, p. 89), que "a concepção que o discurso tem de seu objeto é dialógica".

O autor ressalta, ainda, que todo discurso é voltado também para a resposta de seu ouvinte, que replica ativamente, até mesmo porque ele é que instiga tal resposta. Ao fazer isso, o falante baseia-se no já dito e no que será dito, isto é, naquele discurso que ainda não existe, mas que "foi solicitado a surgir e que já era esperado" (BAKHTIN, 2010, p. 89). O enunciado, assim, além de entrar em contato como outros enunciados que dificultam/modificam seu acesso ao objeto, encontra-se com o fundo aperceptivo do ouvinte, ou seja, como este encarará tal enunciado e reagirá a ele, concordando ou discordando. Dessa forma, a compreensão por parte do ouvinte de um enunciado sempre está associada a uma resposta, a uma posição ativa. 0 enunciado, ao se deparar com essa resposta, é enriquecido com novos 
elementos, tornando-se outro. Por isso, o falante está orientado para seu ouvinte, pois sabe que seu enunciado entrará em contato com um círculo formado por outras concepções, convicções, crenças e dúvidas, um círculo alheio de avaliação e valoração, originando uma espécie de dialogicidade interna do enunciado.

Tendo isso em vista, há: a relação dialógica com o discurso de outrem sobre um mesmo objeto; e a relação dialógica com o discurso de outrem contido na resposta antecipada. Esses aspectos constitutivos do enunciado, que podem ser denominados, respectivamente, dialogicidade externa e dialogicidade interna, auxiliam na formação do estilo, da semântica e da forma composicional do enunciado.

A língua é, assim, estratificada em gêneros do discurso, fazendo com que os elementos da língua estejam associados com a orientação intencional e com o sistema geral de acentuação de um ou outro gênero. Tal estratificação da língua se relaciona de certo modo com a estratificação social como um todo (jargões, gírias, arcaísmos, variações de registros, língua específica de uma profissão etc.), diferenciando-se por formas específicas de interpretação e apreciação concretas e por um vocabulário próprio. Desse modo, para o falante que domina tal estratificação (gênero), essas linguagens parecem plenamente significativas e espontaneamente expressivas. No entanto, para quem está "de fora", para quem não pertence a tal meio, esses recursos expressivos tornam o discurso pesado e alheio. Essa estratificação social "se expressa por diferenças padronizadas de acentuação e de atribuição de sentido aos elementos da língua" (BAKHTIN, 2010, p. 97).

Assim, cada época tem sua própria língua, dotada de determinadas acentuações valorativas, e cada camada social, por sua vez, também tem determinadas linguagens socialmente típicas, isto é, formas relativamente estáveis de comunicação. Então, em cada momento de sua existência, a língua é pluridiscuriva, o que se deve à "coexistência de contradições sócio-ideológicas entre presente e passado, entre diferentes épocas do passado, entre diversos grupos sócio-ideológicos, entre correntes, escolas, círculos, etc." (BAKHTIN, 
2010, p. 98). Percebemos, então, que todas essas linguagens consistem, na verdade, em pontos de vista específicos sobre o mundo, isto é, em determinadas perspectivas objetais, semânticas e axiológicas.

Interessante citar também a seguinte passagem: "Estudar o discurso em si mesmo, ignorar sua orientação externa, é algo tão absurdo como estudar o sofrimento psíquico fora da realidade a que está dirigido e pela qual ele é determinado" (BAKHTIN, 2010, p. 99). Isto é, para estudar e compreender o discurso, a palavra viva, é preciso levar em conta a realidade que o gerou (os discursos que têm o mesmo tema, as condições sócio-históricas nas quais se formou, o próprio objeto de seu enunciado etc.) e para a qual ele se orienta (antecipação da resposta de seu ouvinte, intenção discursiva etc.). Podemos afirmar, assim, que a estratificação da língua é determinada por diferentes forças sociais, o que implica uma ausência de neutralidade nas palavras, fazendo da língua, para seu falante, uma percepção plurilíngue concreta sobre o mundo.

Nesse sentido, entendemos que a noção de gênero do discurso é fundamental aos estudos da língua, já que a utilização da língua pelos falantes sempre ocorre com base em tipos relativamente estáveis de enunciados, ou seja, de gêneros do discurso. Isso ocorre uma vez que a língua é aprendida por meio de enunciados concretos proferidos por aqueles que nos rodeiam em situações reais de comunicação discursiva, de modo que aprender a interagir pela fala consiste em saber construir enunciados na forma de determinado gênero, tendo em vista as relações histórico-sociais estabelecidas em cada contexto de produção.

Assim, os tipos de enunciados estão diretamente relacionados ao campo da atividade humana em que foram originados, refletindo, portanto as condições específicas de cada campo (hierarquização das relações sociais vigentes, momento histórico-cultural da sociedade), bem como suas finalidades. Como o uso da língua está presente em todas as áreas da atividade humana, a palavra, embora sirva igualmente a todas elas, faz com que cada uma delas entenda a realidade com base em suas próprias formas de percepção do 
mundo, alterando e influenciado esse meio também de uma forma particular. Desse modo, cada gênero do discurso é voltado a determinados aspectos da realidade, sendo capaz, consequentemente, de comunicar certas noções acerca das coisas e não outras, já que possui certos princípios de seleção e determinadas maneiras de compreensão dessa realidade (BAKHTIN, 2009). Assim, é possível afirmar que a consciência humana (formada justamente a partir dos embates que a palavra trava nos diferentes campos de produção) possui uma série de gêneros interiores que servem para ver e compreender a realidade, o que faz dos gêneros um conjunto de meios de orientação coletiva na realidade.

Um falante, ao construir seu enunciado, sempre leva em conta, assim, tudo aquilo que já foi dito sobre o objeto ou acontecimento em questão e tudo aquilo que ainda será dito, estabelecendo, desse modo, uma relação de diálogo com outros enunciados anteriores pertencentes ao mesmo gênero e suscitando em seu ouvinte, aquele a quem o enunciado se destina, uma resposta, ou seja, uma posição ativa frente àquilo que foi dito. Assim sendo, um enunciado, além de suscitar uma resposta, é ele mesmo uma resposta a outros enunciados precedentes sobre o mesmo tema.

Como as relações sociais ocorrem em grupos, os quais originam a comunicação e são por ela originados, as formas de comunicação são determinadas pelas relações de produção e pela estrutura sócio-política desses grupos. Desse modo, uma mudança estilística, semântica ou composicional nos gêneros reflete alterações que ocorrem na vida social, fazendo do gênero um importante meio para compreender a sociedade.

Então, como todos os gêneros consistem, na verdade, em pontos de vista específicos sobre o mundo, isto é, em determinadas perspectivas sobre certos objetos, e, uma vez que determinadas formas de enunciados estão ligadas a certas formas da realidade que estes auxiliam a compreender, pretendemos perseguir a seguinte questão: de que modo o gênero científico percebe e representa os animais não humanos na prática da experimentação 
científica e de que forma tal visão auxilia a estruturar as relações que com eles estabelecemos?

\section{Como o humano percebe o não humano: o uso de cobaias}

Para a escolha do artigo a ser analisado, utilizamos como recorte temporal o acontecimento das invasões no Instituto Royal, ocorridas em 18 de outubro de 2013. Esse acontecimento foi extremamente importante por trazer à tona o assunto da experimentação animal, envolvendo a mídia e a população em geral nas discussões a esse respeito. Contudo, para demonstrar que a temática da experimentação já estava presente e se fazia importante no discurso de divulgação científica antes disso, optamos por analisar apenas artigos que fossem anteriores a esse acontecimento.

Assim, conforme o que propõe Bakhtin (2010), a fim de compreender os discursos analisados, nossa análise será constituída de dois momentos: o primeiro deles consistirá em uma análise centrada, o máximo possível, no discurso selecionado para investigação; o segundo deles consistirá em uma análise do material selecionado levando em conta outras perspectivas que não a do próprio autor, justamente com o intuito de estabelecer contrapontos e melhor compreender os discursos em questão. Nas palavras de Bakhtin (2010, p. 381):

A primeira tarefa é compreender uma obra da mesma maneira como a compreendeu o próprio autor sem sair dos limites da compreensão dele [...]. A segunda tarefa é utilizar a sua distância temporal e cultural. Inclusão no nosso (alheio para o autor) contexto.

Entendemos que os sujeitos se apropriam do enunciado alheio para produzir efeitos de sentido distintos, de modo que, em qualquer discurso, 0 dizer é mobilizado em função de fins éticos e estéticos, de acordo com o gênero a que pertence. É justamente esse modo de construção de sentido que caracteriza cada gênero do discurso em sua especificidade e aponta para a não neutralidade do discurso, já que toda apropriação ocorre com base em uma 
intenção de modificação dos sentidos. As coisas não existem por si mesmas, não são imanentes: a apropriação e consequente interpretação é que constroem o lugar dos objetos e dos sentidos no mundo.

Tal movimento pode ser compreendido, assim, com base nos apagamentos de valor, evidenciando o jogo de interesses das classes e das organizações jurídico-políticas. Diante disso, é lícito questionar: de que modo os valores das partes envolvidas no discurso científico se refletem na língua?

O artigo selecionado para análise foi publicado em 2002 na Revista Bioética e versa acerca do uso de animais em pesquisas. Essa revista, conforme consta em sua página eletrônica, é uma publicação científica quadrimestral com tiragem de 10 mil exemplares distribuídos gratuitamente.

Os enunciadores desse artigo voltam-se inicialmente ao período do nazismo, remontando ao fato de Hitler ter proibido, após assumir o poder, esse tipo de experimentação. Em seguida, vem a seguinte passagem:

Atualmente se sabe que durante a Segunda Guerra Mundial os nazistas utilizaram seres humanos - sem seu consentimento - como objeto de experimentação, sem dar-lhes a consideração que animais recebiam em laboratórios científicos e hospitais veterinários. Em 1925, Hitler afirmou: "Eu aprendi a desprezar o ser humano do fundo de minha alma". E, em 1926, afirmou também: "Quanto mais eu conheço a espécie humana, mais eu gosto do meu cachorro". Nestas palavras está o ponto crucial das questões éticas relativas ao uso de animais e seres humanos como objeto de experimentações científicas. As questões são: pode alguém amar mais a um animal que a um ser humano? Pode alguém amar mais a doença que a saúde? Pode alguém amar mais a ignorância que o conhecimento do corpo? (RAYMUNDO; GOLDIM, 2002, p. 32-33, grifo do autor).

Nesse recorte, é possível perceber que os enunciadores remontam ao período do nazismo para estabelecer um contraponto com a posição adotada no artigo analisado. No período nazista, a ciência praticada partia do conceito de eugenia, que visava a obter uma raça pura e superior, destituída de todos aqueles que pudessem carregar características genéticas inferiores, como deficientes físicos, por exemplo. Tal concepção levou à esterilização forçada de inúmeros indivíduos e ao massacre coletivo de muitos outros, com o intuito de "melhorar a humanidade" por meio do cruzamento seletivo (GUERRA, 2006). 
Atualmente, o paradigma da eugenia foi negado via desconstrução da ideia de raça, por exemplo. Ao citar Hitler e o nazismo, os enunciadores indicam que a concepção de ciência a que se filiam é outra: uma concepção que não crê na existência de uma raça pura nem na possibilidade de que alguns seres humanos serem superiores a outros.

Ressaltamos, entretanto, que essa menção à Alemanha nazista acaba colocando em voga diversas outras questões além desse posicionamento ideológico. Primeiramente, nesse recorte, aparece o fato de os nazistas terem usado seres humanos em experimentações, fato que não é exclusivo da Alemanha nazista. Como se sabe hoje, nos Estados Unidos, por exemplo, um grupo de 400 pessoas com sífilis foram submetidas a testes sem consentimento; o mesmo ocorreu na União Soviética, quando os russos testavam veneno nos prisioneiros inimigos de guerra; assim como no Japão, tanto em guerras civis quanto na Segunda Guerra Mundial, em que procedimentos como dissecação de pessoas vivas e amputação de membros eram realizados (KOTTOW, 2008). Percebemos, então, que a experimentação em pessoas sem seu consentimento não era tão incomum assim. Mas quais as consequências de escolher justamente o exemplo do nazismo para ser citado e ignorar todos os outros casos de experimentação em humanos? O nazismo é amplamente malvisto, de modo que sua evocação causa aversão e repulsa na maioria das pessoas. Tem-se aqui um primeiro argumento implícito utilizado pelos enunciadores para a aceitação da experimentação em animais não humanos ${ }^{4}$ : onde esses animais são poupados, humanos são testados. Logo, conforme os enunciadores, o amor pelos animais levaria a um sofrimento dos seres humanos, como aconteceu na Alemanha nazista, em que Hitler afirmava desprezar o ser humano e amar o seu cachorro.

\footnotetext{
${ }^{4}$ Utilizaremos a expressão animais não humanos para marcar nosso posicionamento em relação ao tema, embora os enunciadores do artigo analisado não façam uso dessa expressão. Nossa escolha deve-se ao fato de que os seres humanos também são animais e a uma tentativa de fugir do paradigma especista. Ressaltamos, ainda, que tal termo é comum e amplamente utilizado nas discussões acadêmicas e ativistas sobre o tema.
} 
Retomemos o recorte anterior para que seja possível dar continuidade à análise:

\begin{abstract}
Atualmente se sabe que durante a Segunda Guerra Mundial os nazistas utilizaram seres humanos - sem seu consentimento - como objeto de experimentação, sem dar-lhes a consideração que animais recebiam em laboratórios científicos e hospitais veterinários. Em 1925, Hitler afirmou: "Eu aprendi a desprezar o ser humano do fundo de minha alma". E, em 1926, afirmou também: "Quanto mais eu conheço a espécie humana, mais eu gosto do meu cachorro". Nestas palavras está o ponto crucial das questões éticas relativas ao uso de animais e seres humanos como objeto de experimentações científicas. As questões são: pode alguém amar mais a um animal que a um ser humano? Pode alguém amar mais a doença que a saúde? Pode alguém amar mais a ignorância que o conhecimento do corpo? (RAYMUNDO; GOLDIM, 2002, p. 32-33, grifo do autor).
\end{abstract}

Nesse recorte, os enunciadores afirmam que os humanos testados na Alemanha de Hitler não recebiam a mesma consideração que os animais não humanos recebiam em laboratórios científicos e hospitais veterinários. Contudo, o modo como animais não humanos vivem em laboratório, isto é, a que condições são submetidos, ainda não havia sido apresentado no artigo para que os enunciadores pudessem realizar uma comparação entre o modo de tratar os animais e o modo de tratar os seres humanos. Nesse sentido, afirmam que os nazistas negavam aos humanos as benesses que os outros animais recebiam em experimentos, o que se torna, pelo menos, difícil de apreender, uma vez que não sabemos, via artigo, qual seria o tratamento dispensado aos animais não humanos em outras partes do mundo para compará-lo ao tratamento concedido aos humanos durante o regime nazista.

Um último ponto a ser ressaltado aqui consiste no chamamento de uma questão de ordem sentimental: "pode alguém amar mais a um animal que a um ser humano?" (RAYMUNDO; GOLDIM, 2002, p. 33). Tal inserção é curiosa na medida em que um artigo que tem a pretensão de se basear em fatos de ordem lógica, como ainda é o caso da maioria dos discursos das ciências naturais e exatas, que visa a discutir a ética na experimentação animal, traz à tona um questionamento acerca da capacidade de amar de alguém. Ademais, uma pergunta como essa para fazer o texto avançar minimamente em seus 
propósitos precisaria, ao menos, estar embasada em reflexões psicanalíticas se quisesse demonstrar ao leitor de que modo a capacidade de amar tem relação com o tema abordado. Ressaltamos, ainda, que tal questão parece pressupor que existe um modo certo de amar (amar mais os humanos) e um modo errado (amar mais os não humanos). Diante da referência à barbárie cometida no nazismo, torna-se plausível a hipótese de que a não utilização de animais não humanos em experimentos remete à anormalidade (no sentido de patológico) dos acontecimentos, seja pela alusão ao nazismo, seja pelo questionamento da capacidade de "amar certo".

Após ter evocado os experimentos científicos realizados com humanos no período do nazismo, os enunciadores tratam do "ressurgimento do debate sobre a utilização de animais em pesquisas e em outras atividades", trazendo à tona pensadores-chave para compreender esse debate e algumas declarações criadas para regulamentar o tema. Afirmam, então:

Durante a década de 80 , o movimento para eliminar o uso de animais em pesquisas biomédicas cresceu assustadoramente [...]. Alguns grupos radicais na defesa dos direitos dos animais praticaram atentados contra laboratórios, biotérios, instalações universitárias [...] tais grupos protagonizaram mais de 29 ataques a instituições americanas de pesquisa, roubando mais de 2.000 animais (RAYMUNDO; GOLDIM, 2002, p. 34).

Nesse recorte, os enunciadores demonstram certo posicionamento ideológico ao optarem pela utilização de alguns termos, que denotam um julgamento de valor explícito acerca do movimento contra a utilização de animais não humanos em experimentos. $\mathrm{O}$ uso do termo "grupos radicais", por exemplo, indica que os enunciadores percebem as iniciativas de grupos engajados na libertação de animais utilizados em laboratórios como algo extremado que envolve, inclusive, o roubo de animais.

Sob nossa perspectiva, esse posicionamento revela uma visão que considera os animais não humanos um bem ou um objeto que pertence a alguém, pois apenas nessa concepção poderiam ser roubados e não raptados ou levados, por exemplo. Nesse sentido, até agora, o artigo é construído por meio da apresentação de uma síntese do que é desenvolvido em todo o artigo, 
evocando o período nazista e o modo como os experimentos científicos ocorriam nessa época e apresentando algumas atividades de grupos contra a utilização de animais em experimentos.

A seguir, os enunciadores mencionam que

Estas ações atingiram tal magnitude que a Associação Mundial de Medicina publicou uma declaração específica sobre o uso de animais em pesquisas biomédicas, incluindo a necessidade de reunir esforços para proteger pesquisadores e seus familiares (RAYMUNDO; GOLDIM, 2002, p. 34).

Esse recorte indica, então, que as ações que os enunciadores denominaram de radicais levaram à implementação de esforços por parte da Associação Mundial de Medicina para evitar os danos causados pelos grupos radicais. Tem-se, assim, mais um elemento para a progressão temática do discurso em questão: a contrapartida de uma associação de medicina aos atos daqueles que são contra a experimentação. Ao evocar tal associação, os enunciadores colocam-se a favor dos testes científicos em animais, corroborando o posicionamento demonstrado no recorte anterior: de que aqueles que roubam animais de laboratórios causam danos tanto às pesquisas em si quanto aos pesquisadores e seus familiares.

Contudo, sob nosso ponto de vista, o recorte em questão revela o que poderíamos denominar de inversão de papeis: os animais não humanos são utilizados em experimentos, mas quem precisa de proteção são os pesquisadores, isto é, quem faz uso desses animais. Tal proposição é plausível se considerarmos que, em toda a história de manifestos contra o uso de animais não humanos em experimentos, não existem relatos de qualquer injúria causada pelos manifestantes aos pesquisadores. Assim, a afirmação em questão, além de deslegitimar os movimentos antiespecistas, realiza uma inversão da necessidade de proteção: a vítima aqui não é o animal submetido a experimento, mas aquele que o submete.

Em seguida, após citar a iniciativa da Associação Mundial de Medicina, os enunciadores dissertam acerca de outras leis e resoluções criadas para 
regulamentar a utilização de animais não humanos em experimentos. Mencionam que, no Brasil, a Lei de Crimes Ambientais de 1998

\begin{abstract}
estabelece que é crime praticar ato de abuso, maus-tratos, ferir ou mutilar animais silvestres, domésticos ou domesticados, nativos ou exóticos, sob pena de detenção por um período de três meses a um ano e multa. 0 primeiro parágrafo deste artigo diz que "incorre nas mesmas penas quem realiza experiência dolorosa ou cruel em animal vivo, ainda que para fins didáticos ou científicos, quando existirem recursos alternativos" (BRASIL, 1998 apud RAYMUNDO; GOLDIM, 2002, p. 35).
\end{abstract}

Nesse recorte, ao evocar a legislação após ter apresentado o imbróglio entre aqueles que são contra os testes (grupos que praticam atentados contra laboratórios) e aqueles que são a favor (Associação Mundial de Medicina, por exemplo), os enunciadores filiam-se ao que prevê a Lei de Crimes Ambientais: que a prática de experimentos, ainda que cruéis ou dolorosos, é permitida caso não existam recursos alternativos. Assim, o discurso de outrem, isto é, da legislação, é trazido ao artigo ora analisado para sinalizar a aceitação de uma prática (a dos testes em animais) que é legal do ponto de vista jurídico, ainda que do ponto de vista ético possa ser discutida.

Diante disso, podemos perceber que a proibição de experimentos dolorosos só ocorre em caso da existência de recursos alternativos. Ou seja, o bem-estar do animal não humano submetido à experimentação só precisa ser respeitado se houver outras formas de efetuar o mesmo teste. Novamente, não há nenhuma consideração sobre a vida desse animal em si, que seja independente da vida dos animais humanos. A existência daquele está condicionada ad eternum à existência deste, de modo que sua vida só será respeitada se ele não for "necessário" para as experiências.

Após discorrer sobre a Lei de Crimes Ambientais, os enunciadores detalham os aspectos éticos envolvidos na experimentação em animais, questão que consiste no objetivo principal do artigo. Nesta seção, é realizado um percurso histórico da temática por meio da citação de inúmeros pensadores que trataram da condição dos animais em nossa sociedade: Michel Montaigne, René Descartes, David Hume, Jeremy Bentham, Claude Bernard, William M.S. 
Russell, Rex L. Burch, Peter Carruthers, Peter Singer, Albert Schweitzer, Robert Veatch e Tom Regan. Sobre Descartes, os enunciadores do artigo afirmam que talvez as diferenças entre os homens e os animais assinaladas pelo pensador francês

tenham influenciado os cientistas do século XVII a realizarem seus experimentos sem questionar o uso de animais. As considerações deste pensador de que os processos de pensamento e sensibilidade correspondem à alma talvez tenham levado os cientistas da época a pensarem que por serem desprovidos de uma alma "racional" não havia possibilidade dos animais sentirem dor (RAYMUNDO; GOLDIM, 2002, p. 37, grifo do autor).

Ressaltamos aqui uma questão importante para refletir sobre a temática que surgirá novamente nas proposições dos outros estudiosos citados: a relação entre corpo e alma. Descartes parte do princípio de que, se os animais não humanos não têm alma, logo não podem sentir dor. Lembremos que essa justificativa foi a mesma utilizada pelos portugueses ao colonizarem o Brasil em relação aos índios: não têm alma, portanto podem ser escravizados. Contrapondo os fundamentos da base escravista, o inglês Bentham (1789) afirmou:

Os franceses já descobriram que a cor preta da pele não constitui motivo algum pelo qual o ser humano possa ser entregue, sem recuperação, ao capricho do verdugo. Pode chegar o dia em que se reconhecerá que 0 número de pernas, a pele peluda, ou a extremidade dos sacrum constituem razões igualmente insuficientes para abandonar um ser sensível à mesma sorte. Que outro fator poderia demarcar a linha divisória que distingue os homens de outros animais? Seria a faculdade de raciocinar, ou talvez a de falar? Todavia, um cavalo ou um cão adulto é incomparavelmente mais racional e mais social e educado que um bebê de um dia, ou de uma semana, ou mesmo de um mês. Entretanto, suponhamos que o caso fosse outro: mesmo nessa hipótese, que se demonstraria com isso? O problema não consiste em saber se os animais podem raciocinar; tampouco interessa se falam ou não; o verdadeiro problema é este: podem eles sofrer? (apud RAYMUNDO; GOLDIM, 2002, p. 37).

Ao apresentar ao leitor o percurso histórico dos aspectos éticos ligados à experimentação animal, os enunciadores vão contrapondo diferentes bases argumentativas acerca da temática: trazem pensadores que foram a favor da experimentação e pensadores que foram contrários à realização dos testes em 
animais. Assim, apresentam primeiramente Descartes, que entendia, segundo os enunciadores, que somente os homens eram sensíveis à dor, e, após, evocam o pensamento de Bentham, que acreditava que os animais eram passíveis de sentir dor.

Aqui Bentham (1789 apud RAYMUNDO; GOLDIM, 2002) propõe uma reflexão interessante: não estariam os animais submetidos hoje às mesmas condições que negros (e índios) foram submetidos anteriormente? Além disso, qual seria a característica que, verdadeiramente, deveria ser levada em conta? Ele responde-nos: a capacidade de sofrer. Os animais não humanos, assim como negros e índios já foram, são vistos como inferiores e, por isso, podem (e devem) servir ao ser humano. Necessário observar, contudo, que essa decisão de quem é ou não inferior advém, curiosamente, daquele que sempre se julga superior. Dessa forma, parece uma luta injusta e eternamente invencível: os parâmetros estabelecidos para analisar a superioridade são aqueles característicos da espécie que tem interesse em dominar outros seres (de sua própria espécie ou não). Stephen Jay Gould, em 1991 no livro $A$ falsa medida do homem, discorre sobre a validade dos testes de QI realizados antigamente. Quando surgiram, as características biométricas relacionadas ao resultado do teste de QI eram baseados na fisiologia de homens (sexo masculino) brancos, indo-europeus. Assim, obviamente, todos aqueles de outras etnias apresentavam, como se espera, diferenças, consideradas na época como sinal de inferioridade. Além disso, muitas pessoas submetidas ao teste não dominavam a língua em que este era aplicado ou não sabiam escrever; logo, obtinham pontuação mais baixa. Consequentemente, os diferentes tinham QI menor, resultado falacioso conforme a leitura de Gould.

Os enunciadores mencionam, então, que, a partir das colocações de Bentham, inúmeras questões sobre a experimentação animal podem ser levantadas: 
resultados encontrados em estudos realizados em animais (RAYMUNDO; GOLDIM, 2002, p. 37-38).

Ressaltamos, contudo, que o direito dos homens de utilizar animais como cobaias não é colocado em xeque, de fato, no artigo, assim como a validade da transposição dos resultados. Os enunciadores apenas citam essas questões, mas não discutem se esse direito existe ou não e se os resultados obtidos nos testes realizados em animais não humanos podem ser extensíveis aos humanos, como veremos a seguir. Discorre-se sobre a manutenção do bemestar animal em laboratório, as leis que surgem para esse fim, a premissa de recorrer a cobaias apenas quando não houver métodos alternativos e as características apontadas por outros estudos acerca das diferenças entre animais humanos e não humanos. Mas o direito de utilizar ou não esses animais não é discutido em seu cerne. Poderíamos afirmar, a partir da leitura atenta do texto em questão, que sua base consiste em apresentar um percurso histórico da utilização de animais não humanos em experimentos e não sobre a legitimidade de tal prática.

Continuando a apresentação desse percurso histórico, Raymundo e Goldim (2002, p. 38) afirmam, então, que

Provavelmente a partir das idéias de Bentham (1748-1832) aparecem as primeiras ações com relação à proteção aos animais. Em 1822, é instituída a Lei Inglesa Anticrueldade (British Anticruelty Act). Esta regra foi também chamada de Martin Act, em memória de seu intransigente defensor Richard Martin.

Aqui temos dois pontos a serem discutidos: 1) o surgimento de práticas a partir de determinados estudos; e 2) a classificação de um dos defensores da lei como intransigente. Assim como os enunciadores já apontaram no caso de Descartes, afirmando que teria sido a partir de suas ideias que os cientistas realizaram experimentos em animais sem questionar essa conduta, o fazem em relação às proposições de Bentham, demonstrando uma visão binária da influência entre ciência e práxis. Parece que a ciência produz suas reflexões de forma apartada da realidade prática, mas influencia essa realidade. Os 
enunciadores não levam em conta que possivelmente a realidade das práticas com animais tenha influenciado esses pensadores a refletirem sobre a questão, em uma via de mão dupla: a ciência influencia a vida e a vida influencia a ciência. O segundo ponto recai sobre o mesmo princípio já discutido aqui - a presença de um julgamento de valor explícito ao utilizar o adjetivo intransigente para designar um dos defensores da lei. Lembramos que esse termo pode caracterizar tanto alguém que não faz concessão, sendo inflexível e intolerante, quanto alguém que é austero e rígido na observância de seus princípios.

Seguindo uma linha temporal de estudos que tangenciam o tema da experimentação, os enunciadores citam a publicação de Charles Darwin, em 1859, da obra A Origem das Espécies, em que o naturalista

\begin{abstract}
estabelece os pressupostos do vínculo existente entre as diferentes espécies animais num único processo evolutivo. Desta forma, a teoria de Darwin possibilitou a extrapolação dos dados obtidos em pesquisas com modelos animais para seres humanos, dando um maior respaldo aos cientistas que utilizavam animais em suas pesquisas. Esta é uma relação paradoxal, pois as constatações de Darwin associadas às investigações que já haviam demonstrado semelhanças importantes entre as estruturas e funcionamento do corpo dos seres humanos e de alguns animais permitiram que estes fossem ainda mais utilizados (RAYMUNDO; GOLDIM, 2002, p. 38).
\end{abstract}

Nesse recorte, é possível perceber que os enunciadores trazem o pensamento de Darwin por meio de um relato, o que permite maior liberdade no modo de transpor o conteúdo e a forma do discurso de outrem ao artigo. Assim, os enunciadores entendem que as colocações darwinianas teriam proporcionado maior segurança aos pesquisados para extrapolar os resultados obtidos em testes com animais aos humanos, uma vez que haveria semelhanças fisiológicas e estruturais entre as espécies animais (humanos e demais animais).

Precisamos, ressaltar que, embora a obra de Darwin tenha influenciado o pensamento científico da época, revolucionando o modo como o ser humano via a si mesmo, seu pressuposto, contudo, é o de que todas as espécies, e não apenas as espécies animais, apresentam vínculo evolutivo entre si. Esse vínculo pode ser explicado pela seleção natural, uma vez que, conforme Darwin (2003), 
apenas aqueles seres adaptados ao meio ambiente em que vivem são capazes de sobreviver e de deixar descendentes férteis para a próxima geração, sendo este o objetivo biológico da existência: passar os genes adiante. Como todas as espécies existentes estão adaptadas ao meio em que vivem, de acordo com os pressupostos de Darwin (2003), todas elas são igualmente evoluídas deste ponto de vista, podendo ser algumas estruturalmente mais simples ou mais complexas. Segundo conclusão dos enunciadores do artigo analisado, a descoberta de Darwin teria respaldado a experimentação animal devido à presença de semelhanças e, consequentemente, à possibilidade de transpor os resultados obtidos.

Em seguida, mencionam que essa questão é paradoxal, pois as semelhanças observadas levaram a uma utilização ainda maior dos animais não humanos em experimentos. Não explicam, contudo, o motivo deste paradoxo: aspecto que compreendemos como essencial para entender o debate atual sobre a experimentação laboratorial e os direitos dos animais de maneira geral. A existência de um paradoxo significa que há uma contradição, questão essencial à existência do ser humano sob uma perspectiva materialista, sendo necessário refletir sobre ela. Assim, se a semelhança entre humanos e não humanos levou ao aumento da realização de testes com estes, qual seria a contradição a que os enunciadores se referem, mas não explicitam?

Sob nossa perspectiva, se existem semelhanças, há uma maior probabilidade de que os resultados obtidos em uma espécie possam ser extensíveis à outra. Entretanto, se existem semelhanças, os princípios válidos para uma espécie e para a outra também devem ser os mesmos. Dessa forma, se os seres são similares, eles deveriam ter os mesmos direitos, o que implica que os animais não humanos, assim como os humanos, sentem dor, frio, medo, fome e outras sensações possíveis àqueles com sistema nervoso central; logo, ao serem utilizados como cobaias, estão sendo submetidos a sensações indesejáveis, não tendo seus direitos preservados. Esse é o paradoxo que os enunciadores não explicam: se são semelhantes, podem, pelo menos em 
teoria ${ }^{5}$, gerar resultados aplicáveis aos humanos; e podem sentir e ter as mesmas sensações.

Após (não) discorrer sobre o paradoxo das implicações da teoria de Darwin, os enunciadores do texto analisado, trazem uma citação de Bernard para justificar "o sacrifício de alguns seres vivos em detrimento de outros" (RAYMUNDO; GOLDIM, 2002, p. 39):

Nós temos o direito de fazer experimentos animais e vivissecção? Eu penso que temos este direito, total e absolutamente. Seria estranho se reconhecêssemos o direito de usar os animais para serviços caseiros, para comida, e proibir o seu uso para a instrução em uma das ciências mais úteis para a humanidade (RAYMUNDO; GOLDIM, 2002, p. 39).

O modo como o discurso de Bernard é apropriado consiste em uma tentativa de justificar o uso de animais não humanos em experimentos com a alegação de que esse uso, menos "nobre" talvez, seja feito em outros campos (como alimentação e transporte). O princípio consiste, assim, em: se esses animais são utilizados para outros fins, também podem ser utilizados para a produção da ciência.

Contudo, ressaltamos que o fato de animais não humanos serem usados para alimentação, por exemplo (o que também não foi questionado, sendo, portanto, complicado transformar este dado na justificativa para outros atos), só reafirma a condição de objeto em que se encontram, explicitando que esse uso ocorre em grande escala na sociedade. É, assim, o mesmo princípio geral: eles são usados em benefício dos humanos, não importando a finalidade. Usase, dessa forma, um acontecimento não questionado, mas questionável, para justificar outro acontecimento que também não se quer questionar: teriam os homens esse direito?

\footnotetext{
${ }^{5}$ Há inúmeros estudos que demonstram que os resultados obtidos na experimentação em animais não humanos, muitas vezes, não podem ser extensíveis aos humanos, ainda que haja semelhanças genéticas consideradas significativas. Conferir, por exemplo: Marras (2002).
} 
Após os enunciadores citam um modelo criado em 1959 por Russell e Burch, o modelo dos três "Rs" da pesquisa em animais (replace, reduce e refine):

Esta proposta não impede a utilização de modelos animais em experimentação, mas faz uma adequação no sentido de humanizá-la [...]. Ela é claramente precursora dos esforços atuais que visam substituir o uso de modelos animais para a realização de pesquisas científicas por técnicas alternativas, reduzir o número de exemplares utilizados e garantir técnicas que minimizem o sofrimento dos animais (RAYMUNDO; GOLDIM, 2002, p. 39).

O modo de apropriação do discurso de Russell e Burch por Raymundo e Goldim indica que o modelo dos três "R" seria uma solução à problemática da experimentação animal, pois humanizaria tal prática. Assim, esse modelo conseguiria aliar os testes científicos em animais a uma prática científica mais humana, isto é, menos causadora de sofrimento aos animais utilizados, além de diminuir a quantidade de animais empregados. Percebemos, então, que a apropriação desse discurso serve diretamente aos interesses dos enunciadores do artigo, uma vez que defende a "humanização"6 das práticas envolvendo animais como a solução aos embates de cunho ético, levando à ideologia que irá dominar no texto.

Esse modelo busca, conforme explicam os enunciadores, humanizar a experimentação com animais não humanos, lembrando que o verbo tem a acepção de conceder condição humana ou tornar tolerável/amenizar. Uma vez que a experimentação laboratorial com humanos só é permitida atualmente se houver consenso destes, dentre outros quesitos que devem, obrigatoriamente, ser respeitados, o sentido do termo aqui parece ser o de amenizar. Percebamos, contudo, que este é um verbo que exige complemento, sendo preciso responder à seguinte questão: amenizar o que? O sofrimento. Isso pode

\footnotetext{
${ }^{6} \mathrm{~A}$ tentativa de humanizar as práticas com animais é também conhecida como bem-estarismo. Esta expressão designa medidas que buscam promover o bem-estar dos animais quando usados pelos humanos. Trata-se, portanto, de uma posição ideológica que intenta legitimar o emprego de animais não humanos para beneficiar os humanos, revestindo-o de um caráter humanitário.
} 
ser confirmado se analisarmos o terceiro " $R$ " presente no recorte supracitado refine, ou seja, "garantir técnicas que minimizem o sofrimento dos animais" (RAYMUNDO; GOLDIM, 2002, p. 39). Tal concepção admite que a experimentação em animais não humanos causa sofrimento a estes.

Em seguida, os enunciadores apresentam a reflexão de um dos principais pensadores contemporâneos sobre a condição dos animais na sociedade: Peter Singer. Este defende a igualdade entre os seres humanos e os outros animais com base no princípio da igual consideração de interesses. Sob a perspectiva de Singer, uma vez que aceitamos que os outros membros da nossa espécie têm os mesmos direitos que nós, devemos estender essa forma de raciocínio a todos os animais:

A capacidade de sofrer ou de desfrutar coisas é a característica que confere a um ser, seja ele humano ou animal, o direito à igual consideração. Se um ser sofre, não pode haver nenhuma justificativa de ordem moral para nos recusarmos a levar esse sofrimento em consideração (SINGER, 1994 apud RAYMUNDO; GOLDIM, 2002, p. 40).

Ao encontro dessa percepção, os enunciadores citam Tom Regan, que entende que todos aqueles que são sujeitos de uma vida - têm crenças e desejos, percepção, memória, senso de futuro (incluindo seu próprio futuro), sentimentos de prazer e dor, habilidade para iniciar uma ação perseguindo seus desejos e objetivos etc. - possuem o mesmo valor intrínseco, merecendo, portanto, os mesmos direitos, não podendo ser tratados como meros objetos.

Após tais considerações, Raymundo e Goldim (2002, p. 41) afirmam que

As pesquisas com animais são realizadas há milhares de anos e é inegável que trazem benefício para 0 desenvolvimento da ciência e de novas tecnologias, principalmente na área da saúde. A partir das considerações apresentadas neste artigo, conclui-se que o uso de animais em atividades científicas deve ser substituído, sempre que possível, por outras alternativas.

Diante da análise dos recortes apresentados, é possível notar que a posição ideológica dos enunciadores é de que as pesquisas com animais não humanos, embora devam ser substituídas por métodos alternativos quando possível, precisam ser realizadas por dois motivos: 1) porque sempre foi assim; 
e 2) porque trazem benefícios para a ciência e a tecnologia. Podemos perceber, então, que o tema da experimentação em animais não humanos é visto como complexo, uma vez que os enunciadores apresentam, por exemplo, pensadores com visões opostas sobre a mesma temática. Apesar de tal complexidade, a utilização de animais é entendida como necessária ao progresso da ciência.

\section{Algumas considerações}

$\mathrm{O}$ artigo analisado apresenta um posicionamento bastante evidente sobre o tema a que se refere: é favorável à experimentação em animais não humanos em prol do progresso da ciência. A partir da análise, podemos afirmar que o emprego de animais em estudos científicos ainda é indispensável em muitos casos, conclusão que a chegam os enunciadores do artigo em questão. Para chegar a tal conclusão, são apresentados julgamentos de valor que acabam denunciando seus posicionamentos ideológicos acerca da temática, tal como se depreende no seguinte recorte:

Alguns defensores mais radicais dos direitos dos animais argumentam que, como estes são diferentes do ser humano, nada do que se estuda neles ajuda a entender a nossa espécie. Nada mais falso, já que todas as células vivem em conseqüência de um concerto de reações químicas muito semelhantes em todos os organismos - desde os mais simples até o Homo sapiens (RAYMUNDO; GOLDIM, 2002, p. 26, grifo nosso).

Esse recorte denota que, para quem entende a ciência e seu progresso como um fim genuíno que justifica o sacrifício de seres vivos de espécies diferentes da humana, aqueles que lutam contra a experimentação animal são vistos como radicais e seus atos entendidos como prejudiciais ao desenvolvimento científico. O mesmo processo ocorre com o que podemos denominar neste estudo de apelo ao leitor. Isso é feito, por exemplo, por meio de uma referência ao nazismo, ficando os avanços proporcionados pela experimentação menos explícitos. Neste caso, é lícito supor que, por se tratar de um público leitor pertencente à própria comunidade científica e, portanto, conhecedor dos diversos resultados da experimentação animal, não seria 
necessário citar tais avanços. Sendo assim, parte-se para uma memória cultural, retomada para lembrar que, no nazismo alemão, Hitler desprezava o ser humano e amava seu cachorro, permitindo que a experimentação ocorresse em humanos. Além disso, conforme os enunciadores desse artigo, seria moralmente errado, ou pelo menos duvidoso, amar mais seres de outras espécies que os de nossa espécie, o que fica implícito na citação de Hitler "Quanto mais eu conheço a espécie humana, mais eu gosto do meu cachorro" (RAYMUNDO; GOLDIM, 2002, p. 33) - acompanhada das seguintes perguntas: "pode alguém amar mais a um animal que a um ser humano? Pode alguém amar mais a doença que a saúde? Pode alguém amar mais a ignorância que o conhecimento do corpo?" (RAYMUNDO; GOLDIM, 2002, p. 33). Tais questionamentos não são respondidos diretamente no artigo, embora sua própria presença, bem como a condução dos outros argumentos selecionados ao longo do artigo, evidencie o posicionamento dos enunciadores a seu respeito.

A partir disso, evidenciam-se os interesses que movem o gênero de discurso científico: quer-se o produto do labor científico independentemente dos recursos (sacrifício e sofrimento animal) que sejam necessários para isso. A possibilidade de substituir o uso de animais por métodos alternativos exigiria uma reestruturação no modo de fazer ciência, o que, seja por aspectos econômicos, seja por alienação, acaba por não ocorrer ou acontece a passos lentos.

A partir da análise realizada, podemos perceber que, sob a perspectiva dos enunciadores do artigo, o sofrimento ou a morte animal leva a avanços na ciência, como a criação de medicamentos que salvam vidas humanas. Recorrese, assim, à citação de "produtos" dos testes em animais que são do conhecimento do leitor por estarem presentes em seu cotidiano, mas não se estabelece em nenhum momento a discussão acerca do direito que o ser humano arroga a si mesmo de sacrificar vidas de seres de outras espécies em benefício de sua. 
Tal negligência pode ser explicada pela afirmação dos enunciadores do artigo de que, para todos esses avanços ocorrerem, é imprescindível o uso de animais. Se tal debate fosse, contudo, realizado de outra forma, isto é, se abordasse o direito ou não de utilizar animais não humanos em experimentos, independente das consequências disso, e se chegássemos ao consenso de que tal direito não existe (falamos em consenso porque muitos pesquisadores do tema já demonstraram a validade de tal perspectiva), seria necessário abandonar o status quo do atual modo de produzir ciência. Dessa forma, a premissa de que os fins justificam os meios (sacrificar vidas em detrimento de outras) e de que o progresso deve ser alcançado a qualquer custo teria de ser revista. Enquanto tal mudança de perspectiva não for feita, o pressuposto de que algumas vidas valem mais que outras continuará sendo utilizado e aceito pela população.

Esse pressuposto da valoração da vida conforme a espécie à que pertence é um dos pilares da forma como nos relacionamos com os animais não humanos: o especismo. O termo "especismo" foi proposto em 1970 pelo psicólogo britânico Richard Ryder e popularizado pelo filósofo australiano Peter Singer (BRÜGGER, 2009). Conforme Peter Singer (1998, p. 25),

o especismo pode ser definido como qualquer forma de discriminação praticada pelos seres humanos contra outras espécies. Como o racismo ou o sexismo, o especismo é uma forma de preconceito que se baseia em aparências externas, físicas etc. A simples constatação de uma diferença é usada como um pretexto ou motivo para a não aplicação do princípio ético da igualdade, entendida como igual consideração de interesses. Mas os pretextos que supostamente justificariam essa discriminação não procedem. $\mathrm{Na}$ ética utilitarista, ser passível de sofrimento é a característica que diferencia os seres que têm interesses - os quais deveríamos considerar dos que não os têm. A condição de "senciente" (capacidade de sofrer ou experimentar prazer ou felicidade) é, portanto, suficiente para que um ser vivo seja considerado dentro da esfera da igual consideração de interesses. A crítica ao especismo é especialmente elucidativa para repensarmos atitudes nossas tão arraigadas como saborear a carne de um animal, um interesse muito pequeno quando comparado à vontade de viver daquele animal.

Outra definição possível para o especismo é a apresentada por Garry L. Francione (2000), para quem o especismo se fundamenta no pertencimento à 
espécie humana como argumento para justificar o estatuto de propriedade dos animais não humanos, instaurando, conforme observa Trindade (2013), um elemento novo a essa noção: o paradigma legal no qual o especismo está assentado. Dessa forma, o especismo não está desvinculado da ação de usar um indivíduo, no sentido de condicioná-lo ao estatuto de mero recurso econômico.

Francione (2000) afirma que especismo, racismo e sexismo são comportamentos similares, pois se assentam na premissa de que certas características biológicas determinam se um ser pode ser alvo de igual consideração moral ou não. De acordo com Trindade (2013), a escravidão humana e a exploração animal são semelhantes, pois humanos e não humanos em tais condições têm o seu interesse de não sofrer violado sob a justificativa de que, por meio da adoção de características fisiológicas arbitrárias (como espécie e raça, por exemplo), é possível definir sobre quem terá o seu interesse em não sofrer considerado como importante.

O especismo pode ser entendido, assim, como análogo ao racismo. Neste sistema de pensamento, os racistas pressupõem que pessoas com determinadas características fisiológicas diferentes das suas têm menor valor. No especismo, ocorre algo que segue o mesmo princípio: supõe-se que os fatores biológicos que diferenciam a espécie humana das outras originam um valor moral que as outras espécies não teriam. Acredita-se, dessa forma, que a espécie humana, por ser dotada de uma suposta superioridade, tem o direito de se apropriar de outras espécies a seu bel-prazer. Logo, se o uso de animais não humanos é aceito, devido à sua inferioridade em relação aos humanos, o sofrimento a que as cobaias são submetidas nos laboratórios, por exemplo, torna-se irrelevante - ou pelo menos não consiste em um motivo para que tais práticas não ocorram, como foi possível perceber no artigo científico analisado neste estudo.

Precisamos levar em conta, entretanto, que, de acordo com Francione (2008), os animais empregados em experimentos científicos, assim como os humanos, são seres sencientes, ou seja, possuem uma consciência acerca de si 
mesmos e, portanto, preferem uma coisa em detrimento de outra. Justamente por serem dotados de senciência, os animais não humanos deveriam ser tratados sob a perspectiva da igual consideração de interesses, o que significa que 0 interesse de continuar vivo ou de não sofrer tem o mesmo valor para indivíduos sencientes, sejam eles humanos ou não. Contudo, com exceção de países como Nova Zelândia e França, que recentemente reconheceram os animais como seres sencientes e, portanto, sujeitos de direito, nos demais locais do globo, os animais ainda são vistos como coisas e, consequentemente, como propriedade. Não há, assim, um reconhecimento da vontade de viver como intrínseca a esses seres.

Essa premissa pode ser facilmente visualizada, por exemplo, na própria designação do homem como ser humano e de todos os outros animais como apenas animais (o homem também é um animal). Instaura-se, assim, uma barreira também linguística entre uma espécie e todas as outras, ignorando os próprios princípios da classificação das espécies proposta por Darwin e aceita como paradigma na comunidade científica. Conforme observa Ryder (2011, p. 50),

A partir de Darwin, os cientistas passaram a concordar que não há uma diferença essencial "mágica" entre humanos e outros animais, biologicamente falando. Por que, então, fazemos essa distinção moral quase absoluta? Se todos os organismos estão em um contínuo físico, então nós também devemos estar no mesmo contínuo moral (grifo do autor).

As considerações de Ryder (2011), criador do termo especismo, instigam outros questionamentos ainda. Se todos os seres são igualmente evoluídos da perspectiva científica, o que faz com que o ser humano arrogue a si certa superioridade que emprega como justificativa para se utilizar de animais de outras espécies conforme julgar conveniente? Essa superioridade está de acordo com os paradigmas evolutivos ou apenas facilita o alcance de determinados interesses, possibilitando uma economia de ordem temporal e financeira, por exemplo? 


\section{Referências}

BAKHTIN, Mikhail Mikhailovich. Estética da criação verbal. 5. ed. Tradução Paulo Bezerra. São Paulo: Editora WMF Martins Fontes, 2010.

- Marxismo e Filosofia da Linguagem: problemas fundamentais do método sociológico da linguagem. Problemas fundamentais do Método Sociológico na ciência da Linguagem. Tradução Michel Lahud e Yara Frateschi Vieira. 13. ed. São Paulo: Hucitec, 2009.

BRÜGGER, Paula. Nós e os outros animais: especismo, veganismo e educação ambiental. Linhas críticas, Brasília, v. 15, n. 29, p. 197-214, 2009.

DARWIN, Charles. A origem das espécies. São Paulo: Hemus, 2003.

DAWKINS, Richard. O gene egoísta. São Paulo: Itatiaia, 1979.

FRANCIONE, Garry Lawrence. Animals as persons: essays on the abolition of animal exploitation. New York: Columbia University Press, 2008.

. Introduction to animal rights: your child or the dog? Philadelphia:

Temple University Press, 2000.

GOULD, Stephen Jay. A falsa medida do homem. São Paulo: Martins Fontes, 1991.

GUERRA, Andréa Trevas Maciel. Do holocausto nazista à nova eugenia no século XXI. Ciência \& Cultura, São Paulo, v. 58, n. 1, p. 4-5, 2006.

KOTTOW, Miguel. História da ética em pesquisa com seres humanos. Revista Eletrônica de Comunicação, Informação \& Inovação em Saúde, Rio de Janeiro, v. 2, p. 7-18, 2008.

MARRAS, Stelio. Ratos e homens e o efeito placebo: um reencontro da cultura no caminho da natureza. Campos, Curitiba, v. 2, p. 117-133, 2002.

MEDVIÉDEV, Pável Nikoláievitch. O método formal nos estudos literários: introdução crítica a uma poética sociológica. Tradução Sheila Camargo Grillo e Ekaterina Vólkova Américo. São Paulo: Contexto, 2012.

RAYMUNDO, Marcia Mocellin; GOLDIM, José Roberto. Ética na pesquisa em modelos animais. Revista Bioética, Brasília, v. 10, n. 1, p. 31-44, 2002.

RYDER, Richard Dudley. Speciesism, painism and happiness: a morality for the twenty-first century. Exeter: Imprint Academic, 2011. 
SINGER, Peter. Ética prática. 2. ed. Tradução Jefferson L. Camargo. São Paulo: Martins Fontes, 1998.

TRINDADE, Gabriel Garmendia da. Animais como pessoas: a abordagem Abolicionista de Gary L. Francione. 2013. 219 f. Dissertação (Mestrado em Filosofia) - Universidade Federal de Santa Maria, Santa Maria, 2013. 